\title{
DESENVOLVIMENTO PROFISSIONAL DE PROFESSORES DE COMPUTAÇÃO: Uma Análise das Práticas Docentes
}

\author{
Roberta Gondim Britto ${ }^{1}$ \\ Andreia Maria Pereira de Oliveira²
}

\begin{abstract}
RESUMO
Este artigo mostra como professores de computação não licenciados experienciaram o desenvolvimento profissional docente nos anos iniciais do exercício docente no curso de Licenciatura em Computação. A base metodológica para a produção deste artigo está fundamentada nas narrativas desses professores, nos referencias teóricos da sociologia fenomenológica de Alfred Schutz e nos modos de análise fenomenológica indicados por M. Bicudo. Trata-se de uma pesquisa qualitativa, empírica-compreensiva, que tem como objetivo identificar, descrever e analisar experiências de docentes bacharéis ou tecnólogos, da área de computação, sobre a prática docente nos três primeiros anos de atuação como professor formador de futuros docentes de computação. A compreensão dessas práticas mostrou-nos que os participantes compreendem o trabalho docente na dimensão do contexto de vida experienciado por eles, não se orientando em concepções teóricas e/ou pedagógicas.
\end{abstract}

Palavras-chave: Desenvolvimento profissional docente. Prática docente. Sociologia fenomenológica.

PROFESSIONAL DEVELOPMENT OF COMPUTING PROFESSORS:AN ANALYSIS OF TEACHING PRACTICES

\section{ABSTRACT}

This article shows how computing professors with a bachelor's degree experienced professional development in the first years of teaching in the computing graduation. The methodological basis for the production of this article is based on the narratives of these professors, on the theoretical references of the phenomenological sociology by Alfred Schutz's, and on the modes of the phenomenological analysis indicated by M. Bicudo. It is a qualitative empirical-comprehensive research that aims to identify, describe, and analyze professors' experiences with bachelors or technologies degrees, in the field of computing, about their teaching practice in the first three years of experience as a professor mentor of future computing professors. The understanding of these practices showed us that the participants understand the teaching work in the dimension of their experienced life context, not orienting themselves on theoretical and/or pedagogical conceptions.

Keywords: Professional development of professors. Teaching practice. Phenomenological sociology.

Recebido em: $25 / 9 / 2020$

Aceito em: $6 / 12 / 2020$

\footnotetext{
1 Autora correspondente. Instituto Federal da Bahia - Ifba - Campus Porto Seguro. ROD BR 367, Km 57,5 -Fontana I. CEP 44700-000. Salvador/BA, Brasil. http://lattes.cnpq.br/5301957495717566. https://orcid.org/0000-0002-1604-7925. robertagondim@ifba.edu.br

2 Universidade Federal da Bahia - Ufba. Salvador/BA, Brasil. http://lattes.cnpq.br/6664329706421891. https://orcid.org/0000-0002-8011-5179.
} 
Ao abordar a temática do Desenvolvimento Profissional Docente (DPD), Marcelo (2009) nos faz questionar sobre o que versa o DPD. Quais são seus conteúdos e ramificações? O que sabem os professores sobre o trabalho docente e o que devem saber? Que conhecimentos são considerados importantes para a prática docente e como constituímos esses conhecimentos?

Destacamos que essas perguntas têm grande importância para os professores e, principalmente, para aqueles docentes que não passaram por processos formais de preparação para a docência. Respondê-las, apropriadamente, implica compreender o DPD como transformações pelas quais passam os professores enquanto se constituem e se reconhecem como profissionais de ensino e educação.

Nesse sentido, referimo-nos ao DPD como o processo de (re)construção e desconstrução de especificidades do professor e de sua carreira enquanto profissional vinculado a uma instituição de ensino. As especificidades dizem respeito às particularidades do professor, da função docente e sua forma de atuação, além da importância dada à profissionalidade docente e aos valores atribuídos ao ensino e à educação em variados tempos e espaços.

O DPD de professores não licenciados ${ }^{3}$ é um fenômeno social que vem sendo estudado por pesquisadores de diversas áreas, entre elas a de Computação. A literatura tem mostrado a relevância de se estudar o DPD de professores formadores ${ }^{4}$ que atuam nos cursos de Licenciatura em Computação como uma possibilidade de recriação da prática curricular e educativa, de identificação com a profissão docente (principalmente para os docentes bacharéis), de melhoria da compreensão das necessidades do ambiente escolar, de superação de uma formação instrumental, de aprendizado dos saberes docentes e da docência, de mudança nas ações didáticas e, consequentemente, no ensino de computação (CAMBRAIA; ZANON, 2018; SILVA; MATOS; MASSA, 2018; SILVA, 2018; PAIVA et al., 2017; CAMBRAIA; PEDROSO, 2017).

O DPD abrange diversos aspectos da carreira docente que merecem ser estudados e pesquisados, independentemente da área e do nível de atuação. Entendemos que o DPD está associado a aspectos como formação e profissionalidade docente, construção de uma identidade profissional, baseada em um estoque de experiências anteriores às próprias ações do professor, e também nas demandas sociais internas e externas da instituição de ensino, além das competências e do desenvolvimento de habilidades próprias do ato de ensinar adquiridas no exercício do trabalho docente (GORZONI; DAVIS, 2017).

Este estudo mostra a parte do DPD que está associada às experiências das práticas docentes; tendo como objetivo identificar, descrever e analisar experiências de professores não licenciados, da área de Computação, sobre a prática docente, quando começaram a ensinar no curso de Licenciatura em Computação. Ressaltamos que uma das autoras deste artigo é uma professora formadora, não licenciada, da área de computa-

\footnotetext{
Consideramos professores não licenciados aqueles profissionais que fizeram a sua formação inicial em cursos de Bacharelado ou em Cursos Superiores de Tecnologia, ou seja, os bacharéis e/ou tecnólogos.

4 Consideramos professor formador o docente que atua nos cursos de formação de professores, isto é, o docente atuante nos cursos de Licenciaturas.
} 
ção, que participa da própria estrutura da pesquisa, partindo da sua própria trajetória e da literatura para fundir horizontes com dados produzidos por outros na percepção do fenômeno estudado. Por isso, o uso dos pronomes na primeira pessoa do plural.

Nesse momento, nossa atenção volta-se para as vivências que foram experienciadas pelos formadores nos três primeiros anos de atuação na Licenciatura em Computação. Esse período foi escolhido tomando como base as fases da carreira docente definidas por Huberman (2000), que considera os três primeiros anos de atuação do professor como a entrada e o tateamento na carreira docente.

Para mais, atentamo-nos a perceber as condutas docentes, ou seja, aquelas ações e relações sociais que estavam envolvidas na prática educativa quando nós, professores de computação, começamos a atuar como formadores. A partir da percepção dessas condutas, compreendemos a prática docente como sendo uma parte do trabalho do professor, representada por uma "ação no mundo exterior, baseada em um projeto e caracterizada pela intenção de realizar o estado de coisas projetado" (WAGNER, 1979, p. 124).

Além desta seção introdutória, o texto encontra-se organizado em mais três seções. Na próxima, apresentamos nossa fundamentação construída com a discussão teórica e revisão de literatura. Em seguida, mostramos nossa análise fenomenológica sobre as narrativas dos docentes bacharéis ou tecnólogos, da área de Computação, que formam licenciados em computação. Por fim, trazemos uma síntese compreensiva, mostrando algumas implicações do fenômeno pesquisado.

\section{FUNDAMENTAÇÃO TEÓRICA}

Schutz (2018) coloca-nos diante do seguinte questionamento: "Seria o ser social do indivíduo determinante da sua consciência, ou, antes, a sua consciência condicionante da sua sociabilidade?" (p. 22). Esse questionamento leva-nos a perceber que os aspectos epistemológicos e ontológicos da pesquisa fenomenológica não podem se voltar somente a fatos particulares do ponto de vista do pesquisador. A análise do mundo deve ser feita a partir dos elementos constitutivos do agir social e das relações sociais intersubjetivas que deles derivam. Desse modo, é possível apreendermos o sentido dos fenômenos sociais repletos de ações humanas como uma construção de mundo com conteúdo compreensível de sentido (Ibid).

As pesquisas sobre o DPD de professores formadores não licenciados podem acarretar transformações nos nossos modos de experienciar o mundo, provocando novas ações com resultados diferenciados em nossos trabalhos (trabalho aqui compreendido como ação no mundo exterior). Assim, quando compreendemos que as ações humanas são condutas previstas baseadas em um projeto preconcebido, podemos dar sentido e significado ao trabalho docente, interpretando-o fenomenologicamente a partir de um procedimento ideal tipificante e/ou das categorias de motivações que nos levam a agir de uma ou outra forma.

Ao conceber o DPD como um processo social repleto de ações humanas, assumimos o pensamento de Schutz (2018), que enfatiza os fenômenos sociais e busca examinar como as pessoas percebem e atribuem sentido e significado às suas ações no 
mundo social. Consideramos as práticas docentes dos professores formadores como ações humanas afetadas por diversos contextos sociais e redes de relacionamentos interpessoais. Nessa direção, configuramos uma abordagem fenomenológica do agir social, visando a compreender o DPD dos professores bacharéis ou tecnólogos, da área de computação, atuantes na Licenciatura em Computação.

Para darmos sentido e significado às ações praticadas pelos docentes, partimos do pressuposto de que vivemos com e para outras pessoas, pelas quais orientamos nossas atividades cotidianas. Desse modo, percebemos que as ações sociais praticadas pelos docentes são influenciadas por uma série de acontecimentos e pessoas que fazem parte de um mundo social já constituído, no qual podemos estar voltados, por exemplo, em ação e/ou em observação. O mundo social, em que passado, presente e futuro se misturam, refere-se ao mundo da vida compreendido pelo teórico como sendo um mundo intersubjetivo que é cena e objeto de nossas ações e interações (SCHUTZ, 2018).

Para que pudéssemos compreender as experiências da prática docente do formador não licenciado, primeiramente foi preciso entender o que realmente vem a ser uma prática docente. Nessa busca, percorremos a literatura especializada e percebemos que o sentido e a direção das práticas docentes provêm da fundamentação das práticas pedagógicas (FRANCO, 2016). Segundo a autora, a prática docente construída pedagogicamente configura-se como uma ação consciente e participativa. É um acontecimento que deve ser instituído em torno de intencionalidades, provocando reflexão contínua e coletiva (Ibid).

De fato, a postura reflexiva, quando inserida na prática docente, conforma-se como uma ação consciente que possibilita sentido e significado às intencionalidades do professor formador. Para Schutz (2018), sentido refere-se a uma interpretação de uma experiência passada contemplada desde agora por meio de uma atitude reflexiva. Ter consciência ou ser consciente é estar no mundo e participar da sua construção histórica e social. Nesse movimento de construção e reconstrução do mundo da vida, retornamos às intuições originárias, ou seja, ao modo como os fenômenos nos aparecem, e percebemos uma multiplicidade de aspectos que lhes são próprios (Ibid).

Neste artigo configuramos as práticas docentes como práticas sociais com ações projetadas pelos docentes a partir de uma vivência de consciência doadora de sentido (SCHUTZ, 2018). Para o teórico, nem todas as vivências são doadoras de sentido. Compreendemos que somente aquelas experiências que exigiram um ato de tomada de posição podem ser vistas como doadoras de sentido. "A vivência fenomenal jamais será o comportar-se, senão o ter-se-comportado" (Ibid, p. 89). Refere-se a uma vivência passada que, agora, mostra-se diante dos olhares retrospectivos das pessoas interessadas. Assim, com a mente do presente, mas avistando um porvir, percorremos a duração (durée) para mostrar o sentido do DPD de professores de computação não licenciados que formam futuros licenciados em computação.

Quando paramos para escutar e analisar a prática do nosso semelhante, refletimos sobre nossas próprias práticas. Nesse caso, estamos na presença de dois processos autointerpretativos: um doado pelo participante da pesquisa e outro aferido pelo 
pesquisador. Ambos entrelaçados intersubjetivamente. Isso implica que quanto mais refletirmos sobre a prática docente mais apurado será nosso DPD, e quanto mais polido nosso DPD melhor poderá ser nosso processo de criação e ampliação do mundo social.

A compreensão fenomenológica de como docentes formadores experienciaram o DPD (nos anos iniciais de atuação no curso de Licenciatura em Computação) leva-nos a uma reflexão das nossas práticas pedagógicas concomitantemente com o nosso ter-se-comportado. Nesse caminhar, a sociologia fenomenológica coloca-nos diante de uma análise descritiva do agir, demonstrando que as ações sociais são frutos de um projetar do agir que pode ter o caráter de possibilidade e cuja tomada de posição pode variar (SCHUTZ, 2018).

A próxima seção apresenta nossa análise fenomenológica sobre as narrativas das práticas docentes de professores de computação, não licenciados, nos anos iniciais de atuação na Licenciatura em Computação.

\section{PROCESSO DE INTERPRETAÇÃO FENOMENOLÓGICA DAS NARRATIVAS DE PROFESSORES FORMADORES}

A compreensão ou interpretação fenomenológica é um trabalho que busca pelo sentido do dito na totalidade do descrito (BICUDO, 2011). Nesta seção procuramos o sentido do dito nas narrativas individuais de cada participante da pesquisa. A busca pelo sentido nas experiências individuais de cada professor formador mostrou-nos significados, fazendo-nos compreender os motivos que levaram esses professores a executarem certos tipos de práticas docentes. Também nos fez perceber como o trabalho e a identidade profissional dos professores de computação foram e vêm sendo (re) construídos durante seu processo de desenvolvimento profissional como docente formador.

Os docentes participantes desse cenário são profissionais com titulação de bacharel ou tecnólogo que tiveram formação inicial na área de Computação. Todos eles atuam como professores formadores nos cursos de Licenciatura em Computação do Instituto Federal de Educação, Ciência e Tecnologia da Bahia (Ifba). São, portanto, profissionais não licenciados, mas formadores de futuros professores de Computação.

A escolha dos participantes foi estabelecida, primeiramente, com base na condição de o docente não ter titulação de Licenciado em sua formação inicial e, segundo, se já atuava na Licenciatura em Computação há mais de três anos. Nesse sentido, analisamos os currículos Lattes de professores vinculados aos cursos de Licenciatura em Computação do Ifba e, em seguida, enviamos convites por meio do e-mail institucional, perguntando se o docente teria interesse em participar de uma pesquisa sobre DPD, narrando sua trajetória de vida profissional por intermédio de entrevistas abertas não estruturadas.

Atendidas as condições de titulação e tempo de atuação na Licenciatura em Computação, entrevistamos os participantes que nos deram retorno. Fizemos três entrevistas com cada participante e o tempo médio de duração de cada uma delas variou de 40 a 50 minutos. Não houve filmagem, apenas gravação de áudio para posterior transcrição. 
Em uma investigação fenomenológica, Bicudo (2011) mostra-nos que o ponto crítico da pesquisa é constituído pela interrogação e seu esclarecimento. Segundo a autora, a interrogação é diferente da pergunta que se coloca diante de hipótese posta sob suspeita e de variáveis já determinadas. A interrogação em uma pesquisa à luz da fenomenologia deve direcionar os procedimentos, orientando o pesquisador para onde olhar e o quê olhar (Ibid). Por esse motivo, realizamos entrevistas abertas não estruturadas. Essas ocorreram individualmente, sendo algumas realizadas de maneira on-line (em razão da longa distância existente entre os pesquisadores e o pesquisado) e outras presencialmente.

A entrevista é uma forma bastante utilizada para a produção de dados em pesquisas qualitativas. Pedir às pessoas para compartilharem suas experiências parece ser uma tarefa simples, mas formular um projeto de estudo baseado nessas experiências pode ser um desafio. Desse modo, foi preciso saber quem poderia ser pesquisado; quantas entrevistas seriam suficientes; como formular as perguntas que incentivassem os participantes a responder aberta e honestamente; como obter um relacionamento com os participantes e os envolver em nosso estudo; como transcrever e ordenar os dados, e, por fim, como analisar e interpretar os dados que foram produzidos (LICHTMAN, 2012). Estas foram algumas questões que enfrentamos ao usar a entrevista aberta como procedimento de coleta de dados.

Destacamos que todos os participantes assinaram o Termo de Consentimento Livre e Esclarecido (TCLE), atendendo aos preceitos éticos da pesquisa. A fim de proteger a identidade das pessoas envolvidas, utilizamos pseudônimos, considerando o sigilo sobre a identidade dos professores, ação prevista no TCLE. Ocultamos os nomes reais dos participantes e passamos a usar pseudônimos relativos a nomes de cientistas que contribuíram de forma significativa para a Ciência da Computação, a saber: Marvin Minsky, Ada Lovelace, Claude Elwood Shannon e Carol Shaw.

O fenômeno investigado apresenta-se nas experiências de vida de docentes de computação formadores de futuros professores e faz parte de um estudo maior que busca compreender como professores de computação não licenciados, atuantes em uma Licenciatura em Computação, percebem seu desenvolvimento profissional. Neste artigo, porém, nos limitamos a compreender como esses formadores experienciaram o desenvolvimento profissional nos anos iniciais do exercício docente na Licenciatura em Computação. Para isso, focalizamos as experiências que esses professores têm (ou tiveram) sobre a prática docente logo que assumiram o papel de professor formador.

A seguir, apresentamos o procedimento de análise das descrições narrativas feito por meio das análises ideográfica e nomotética. Na análise ideográfica articulamos as unidades de significado a partir da narrativa de cada participante, enquanto na nomotética reunimos as unidades de significado, buscando as convergências de forma a transcender o aspecto individual apresentado na análise ideográfica. Esses dois modos de análise permitem-nos efetuar reduções sucessivas sobre o fenômeno investigado, "indo em direção às sínteses mais abrangentes do dito e interpretado, buscando as estruturas das experiências vividas que revelam o modo de ser do fenômeno" (BICUDO, 2011, p. 58). 


\section{PRIMEIRO MOVIMENTO DE REDUÇÃO: Análise Ideográfica (articulação das unidades de significado)}

Segundo Bicudo (2011), a análise ideográfica refere-se ao emprego de ideogramas: expressão de ideias por meio de símbolos (letras, números, etc.) que permite mostrar a estrutura do discurso, evidenciando os aspectos noemáticos da descrição. $\mathrm{O}$ adjetivo noemático é referente ao substantivo masculino noema. Este pode ser entendido como uma tentativa de aproximar a compreensão de quem ouve da ideia de quem fala.

Do total de oito participantes, articulamos, nessa etapa, as ideias individuais de quatro deles, buscando, sempre, pelo sentido do dito nas narrativas transcritas dos professores entrevistados. Reduzimos o número de articulações apresentadas em razão do limite do número de páginas do artigo.

O sentido do dito foi evidenciado levando em conta a interrogação desta pesquisa e as experiências vividas dos pesquisadores enquanto professores formadores. Ao nos colocarmos diante das descrições narrativas dos professores, perguntamo-nos: O que é isso que se mostra? Ou seja, o que se manifesta quando perguntamos aos participantes que percepções eles tinham de si enquanto professor e da sua prática quando começaram a lecionar na Licenciatura em Computação? O que se manifestou ou o que se mostrou foram os sentidos do dito pelo olhar das pesquisadoras. Esses sentidos evidenciados nas descrições são identificados por Bicudo (2011) como Unidades de Sentido.

Após colocarmos os sentidos em evidência, partimos para estabelecer as Unidades de Significado. Estas foram estabelecidas em frases, transformando expressões da linguagem cotidiana do participante em uma linguagem condizente com a do campo do inquérito das pesquisadoras. Essa transformação acontece por meio da análise dos significados das palavras, de procedimentos de reflexão sobre o que foi dito e de insights da ideia essencial da narrativa do pesquisado (BICUDO, 2011).

Os quatro depoimentos transcritos seguiram o formato apresentado na pesquisa de Venturin (2015). Esse formato, entretanto, passou por algumas modificações e os depoimentos estão dispostos nos quadros numerados de 1 a 4 logo a seguir. No processo de análise dos dados, expusemos e dispusemos os depoimentos em quadros de maneira que fosse possível evidenciar o movimento de constituição das Unidades de Significado. Assim, a entrevista realizada com os professores formadores está disposta em quadros os quais foram estruturados da seguinte forma: (i) na primeira linha apresentamos o participante da pesquisa; (ii) na segunda linha dispusemos partes das descrições narrativas que consideramos relevantes para esta investigação. Colocamos em evidência os sentidos do dito, pelo entrevistado, manifestado quando eles expressaram compreensão sobre si e sobre o trabalho docente nos primeiros anos de atuação na docência da Licenciatura em Computação. O que está em itálico foi compreendido por nós como Unidades de Sentido (movido pela interrogação da pesquisa), as palavras e/ou expressões em negrito são aquelas que buscamos explicitar o significado no contexto da entrevista. Sinalizamos o recorte das narrativas com mesmo sentido ou para destacar trechos não audíveis na transcrição com o símbolo "[...]"; (iii) na terceira linha apresentamos o significado das palavras e/ou expressões, considerando o contexto do discurso. O enxerto hermenêutico foi feito para que pudéssemos melhor compreender sentidos e significados 
das afirmações expostas nas unidades de sentido, vistas na conjuntura das narrativas e na polissemia das palavras; e, por fim, (iv) expressamos o sentido do dito articulado por nós pesquisadoras, ou seja, as Unidades de Significado. Ademais, para cada participante, sintetizamos as unidades de significados convergentes em ideias que interpretamos.

\section{Quadro 1 - Marvin}

Participante da Pesquisa: o professor Marvin é graduado em Análise de Sistemas. Atualmente ensina as disciplinas de Informática Aplicada à Educação, Metodologia e Prática do Ensino de Computação e Currículo e Novas Tecnologias.

A descrição e o sentido do dito: Perceber a minha prática docente é também revisitar um pouco do meu processo de formação (USM1) ou talvez o reconhecimento enquanto professor, porque o direcionamento que eu dei para as minhas primeiras aulas na Licenciatura em Computação foi muito baseado nas experiências que eu havia tido na minha graduação (USM2). Eu já estava na perspectiva de práticas de ensino ativas (USM3). É algo interessante a refletir porque a minha pesquisa durante o Mestrado foi um pouco direcionada para a minha atuação e para as minhas práticas de ensino que eu desenvolvi em sala de aula. Eu tinha essa visão sobre a utilização de metodologias ativas, a busca do protagonismo do meu aluno, da autonomia do meu aluno (USM4). Então, se eu partisse para uma aula expositiva sem dar espaço para o aluno, trazendo uma característica de aula tradicional, eu estaria, de certa forma, jogando tudo que eu pesquisava no lixo, porque era quase dizer: estou pesquisando mas eu não aplico. [...] Toda essa inquietação de trabalhar de uma forma diferente, de trazer o protagonismo e autonomia para os estudantes nesse processo de construção do conhecimento, já surgem na Graduação (USM5). [...] O grupo de pesquisa me oportunizou a refletir mais sobre extensão, mais sobre pesquisa, principalmente, sobre as práticas de ensino (USM6). [...] Eu estava fazendo todo o processo de planejamento do semestre inteiro e já direcionando e pensando nas alternativas que eu iria trabalhar em sala de aula. [...] Uma parte específica do componente foi para trabalhar PBL (USM7). Eu estruturei um problema fictício para construção de determinados robôs. [...] Reuni todo material que eu tinha de robótica e desenvolvi o problema baseado naqueles materiais que eu tinha. [...] Já havia um professor que também estava atuando na Licenciatura em Computação, que era inclusive um professor licenciado em computação; ele tinha muitas experiências e muitos materiais que ele indicava (USM8). Então, a gente sempre conversava bastante e a gente via um alinhamento bom entre as minhas ideias ainda que eu não seja um licenciado em computação com as dele que era licenciado em computação (USM9). [...] Nesse semestre inicial da minha carreira na Licenciatura em Computação, tivemos uma oportunidade de dividir um componente curricular. [...] Nós dividimos esse componente $e$ planejamos algo que pudesse sair um pouco da esfera do tradicional em que nós aplicávamos um pouco da ideia de sala de aula invertida (USM10). [...] Isso tornou-se algo bem dinâmico e assim eu aprendi bastante tanto da relação professor-aluno como de postura em sala de aula, principalmente por essa coparticipação neste componente com esse professor (USM11). [...] Essa parte pedagógica já faz parte da minha atuação enquanto docente, mas ainda assim eu vou iniciar a minha complementação pedagógica. [...] Espero fazer essa complementação pedagógica até para perceber mesmo se há algumas lacunas nessa ideia do pedagógico que eu tenho enquanto docente e se houver eu acho que vai, de fato, complementar (USM12). [...] Acho que uma outra característica relevante é a ideia de ir aprendendo também junto com os alunos (USM13). [...] Desse ponto de vista de estar sempre produzindo um projeto diferente dentro das aulas, eu percebo que a gente acaba entrando um pouco num tipo de personalização do ensino. [...] Eu costumo esperar um tempo pra perceber qual é o perfil do meu aluno para ir de fato personalizar aquele projeto. $A$ depender de determinados conhecimentos prévios que ele já tenha (USM14), [...] ou um conhecimento que ele vai ter que construir com aquele novo desafio, com aquele novo projeto.

Enxerto hermenêutico: Metodologias ativas: práticas pedagógicas alternativas ao ensino tradicional, centradas na participação efetiva dos estudantes, envolvendo-os na aprendizagem por descoberta ou resolução de problemas (VALENTE, 2018); PBL: Project Based Learning ou Aprendizagem Baseada em Projetos consiste na ideia de possibilitar que o estudante desenvolva seu conhecimento por meio de construção de artefatos que possam ser percebidos e avaliados por outros, agindo ativamente com problemas do mundo real (FERREIRA; CANEDO, 2019); Sala de aula invertida (Flipped Classroom): metodologia de ensino em que o estudante estuda previamente, e a aula torna-se o lugar de aprendizagem ativa, onde há perguntas, discussões e atividades práticas. O professor trabalha as dificuldades dos alunos, em vez de fazer apresentações sobre o conteúdo da disciplina (VALENTE, 2018); Personalização do ensino: estratégias pedagógicas voltadas a promover o desenvolvimentos dos estudantes de maneira individualizada, respeitando as limitações e os talentos de cada um (BACICH, 2016). 


\begin{tabular}{|c|c|c|}
\hline \multicolumn{3}{|c|}{ O sentido do dito articulado pelas pesquisadoras } \\
\hline US da Descrição & $\begin{array}{c}\text { Unidades de Significado articuladas } \\
\text { pelas pesquisadoras }\end{array}$ & $\begin{array}{l}\text { Ideias interpretadas pelas } \\
\text { pesquisadoras }\end{array}$ \\
\hline USM1; USM2 & $\begin{array}{l}\text { 1. Percebe que sua prática docente foi se } \\
\text { constituindo pelas experiências vividas na } \\
\text { Graduação. }\end{array}$ & \multirow{3}{*}{$\begin{array}{l}1 ; 2 ; 3=(01) \text { : Compreende } \\
\text { que a prática docente constitui- } \\
\text { se por experiências de ensino } \\
\text { na Graduação e de reflexões } \\
\text { em grupos de pesquisa no } \\
\text { Mestrado. }\end{array}$} \\
\hline $\begin{array}{l}\text { USM3; USM4; } \\
\text { USM5; USM7; } \\
\text { USM10 }\end{array}$ & $\begin{array}{l}\text { 2. Lembra que desde suas primeiras aulas utilizava } \\
\text { metodologias ativas que havia aprendido na } \\
\text { Graduação. }\end{array}$ & \\
\hline USM6 & $\begin{array}{l}\text { 3. Percebe que o grupo de pesquisa do Mestrado } \\
\text { oportunizou reflexão sobre o trabalho docente } \\
\text { no tripé ensino, pesquisa e extensão. }\end{array}$ & \\
\hline USM8 & $\begin{array}{l}\text { 4. Percebe que recebeu ajuda de um professor } \\
\text { licenciado em computação mais experiente } \\
\text { que indicava materiais. }\end{array}$ & \multirow{3}{*}{$\begin{array}{l}4 ; 5 ; 6=(02) \text { : Compreende } \\
\text { que o trabalho conjunto com } \\
\text { outro professor contribuiu para } \\
\text { uma mudança significativa na } \\
\text { sua própria prática docente. }\end{array}$} \\
\hline USM9 & $\begin{array}{l}\text { 5. Vivenciou discussões alinhadas com o professor } \\
\text { licenciado em computação. }\end{array}$ & \\
\hline USM11 & \begin{tabular}{|l|} 
6. Percebe que aprendeu bastante sobre o trabalho \\
docente quando coparticipou com o professor \\
licenciado em um componente curricular.
\end{tabular} & \\
\hline USM12 & $\begin{array}{l}\text { 7. Entende que a complementação pedagógica é } \\
\text { necessária ao profissional não licenciado que } \\
\text { atua como professor formador. }\end{array}$ & $\begin{array}{l}7 \text { = (03): Entende que a } \\
\text { complementação pedagógica } \\
\text { é importante ao professor } \\
\text { formador. }\end{array}$ \\
\hline USM13 & \begin{tabular}{|l} 
8. \\
$\begin{array}{l}\text { Percebe que aprende também com os } \\
\text { estudantes. }\end{array}$
\end{tabular} & \multirow{2}{*}{$\begin{array}{l}8 ; 9 \Rightarrow(04): \text { Entende que o } \\
\text { envolvimento dos estudantes } \\
\text { e seus perfis direcionam o } \\
\text { trabalho docente. }\end{array}$} \\
\hline USM14 & $\begin{array}{l}\text { 9. Percebe que existe um perfil do estudante que } \\
\text { direciona o trabalho docente. }\end{array}$ & \\
\hline
\end{tabular}

Fonte: As autoras.

Quadro 2-Ada

Participante da Pesquisa: a professora Ada é graduada em Tecnologia em Processamento de Dados. É docente da área de computação desde 2002 e atualmente ensina as disciplinas Algoritmos, Linguagens de Programação e Banco de Dados.

A descrição e o sentido do dito: Quando eu cheguei para lecionar na Licenciatura em Computação eu vinha de cursos superiores na área de computação: Bacharelado em Sistemas de Informação, Engenharia da Computação. [...] Eu vim com a visão de ensino muito tecnicista (USA1). [...] Na Licenciatura, hoje, eu tenho uma visão bastante diferente, mas naquela época eu não tinha. Então, eu acabei replicando as mesmas práticas que eu já utilizava para o pessoal do Bacharelado (USA2). Era aquela visão meramente da área técnica (USA3), de como construir um algoritmo. Não tinha o foco de ensinar a ensinar (USA4). Meu foco era muito mais ensinar os conteúdos (USA5). Eu ainda não tinha tido contato com outros tipos de metodologias diferentes que hoje eu já conheço, mas naquela ocasião eu não conhecia. Então, eu usava bem aquela metodologia tradicional (USA6): trazer o conteúdo teórico, explicar aqueles conteúdos e tentar aplicar na prática usando as ferramentas que a gente tivesse disponível ali naquele momento. Eu também ainda não tinha aquela visão que a gente precisa formar o professor (USA7). Era uma visão que eu ainda não diferenciava. [...] Eu acabei trabalhando com a Licenciatura da mesma maneira que trabalhava com o Bacharelado (USA8). E é interessante que eu percebo hoje, na minha vivência, colegas que estão começando e eles repetem exatamente as mesmas coisas que eu fiz (USA9). [...] A minha visão era bem de tecnólogo mesmo (USA10). [...] Na minha formação eu não tinha o que me amparasse a lidar com a sala de aula, principalmente preparando um professor (USA11). [...] Hoje, quando eu pego minhas aulas do primeiro ano do integrado - Lógica de Programação - a minha aula do primeiro semestre do subsequente também Lógica de Programação e o primeiro semestre do superior, Licenciatura, são diferentes, a ponto até da gente ter currículos diferentes. E em outros tempos não eram (USA12). [...] Quando a gente começou a Licenciatura no Ifba, eu ainda tinha isso de ser muito conteudista (USA13). [...] É o amadurecimento de você reconhecer suas atuações ali e perceber que estão em falha. A gente precisa mudar a abordagem porque senão não faz sentido ter cursos diferentes com a mesma abordagem (USA14). 


\begin{tabular}{|c|c|c|}
\hline \multicolumn{3}{|c|}{$\begin{array}{l}\text { Enxerto hermenêutico: Tecnicista: linha de ensino que privilegia a lógica da instrução e a transmissão da informação } \\
\text { (DA SILVA, 2016); Metodologia tradicional: abordagem pedagógica em que o docente é a pessoa ativa no processo } \\
\text { de ensino e aprendizagem, repassando seus conhecimentos aos estudantes (VALENTE, 2018); Tecnólogo: } \\
\text { profissional de nível superior especializado em uma determinada área de atuação (MACHADO, 2008); Conteudista: } \\
\text { refere-se àquele/a que atribui maior importância ao conteúdo transmitido (SILVA; MATOS; MASSA, 2018). }\end{array}$} \\
\hline \multicolumn{3}{|c|}{ O sentido do dito articulado pelas pesquisadoras } \\
\hline $\begin{array}{l}\text { US da } \\
\text { Descrição }\end{array}$ & $\begin{array}{l}\text { Unidades de Significado articuladas } \\
\text { pelas pesquisadoras }\end{array}$ & $\begin{array}{r}\text { Ideias int } \\
\text { pes }\end{array}$ \\
\hline $\begin{array}{l}\text { USA1; USA3; } \\
\text { USA6; USA10; }\end{array}$ & $\begin{array}{l}\text { 10. Percebe que tinha uma visão } \\
\text { relação ao modo de ensinar e } \\
\text { metodologia tradicional de ensi }\end{array}$ & \multirow{2}{*}{$\begin{array}{l}10 ; 12=>(05) \text { : Entende que o } \\
\text { modo como ensinava era voltado } \\
\text { ao ensino técnico, conteudista e } \\
\text { tradicional. }\end{array}$} \\
\hline USA4; USA7 & $\begin{array}{l}\text { 11. Com } \\
\text { a fo }\end{array}$ & \\
\hline USA5; USA13 & $\begin{array}{l}\text { 12. Perc } \\
\text { dos }\end{array}$ & \multirow{2}{*}{$\begin{array}{l}11 \text { => (06): Entende que a prática } \\
\text { docente adotada no início de } \\
\text { sua atuação na Licenciatura } \\
\text { em Computação visava formar } \\
\text { profissionais da área de } \\
\text { computação. }\end{array}$} \\
\hline USA2; & $\begin{array}{l}\text { 13. Percebe que trabalhava no curso de Licenciatura } \\
\text { do mesma maneira que trabalhava no curso de } \\
\text { Bacharelado. }\end{array}$ & \\
\hline USA9 & $\begin{array}{l}\text { 14. Percebe que colegas novatos repetem as } \\
\text { mesmas práticas que utilizou quando começou } \\
\text { a ensinar na Licenciatura. }\end{array}$ & $\begin{array}{l}\text { 13; } 16 \Rightarrow \text { (07): Compreende } \\
\text { que utilizava a mesma prática } \\
\text { de ensino mesmo atuando em } \\
\text { cursos de diferentes titulações. }\end{array}$ \\
\hline USA11 & $\begin{array}{l}\text { 15. Percebe que na sua formação não recebeu } \\
\text { amparo para atuar em sala de aula. }\end{array}$ & $\begin{array}{l}14=>(08) \text { : Percebe similaridades } \\
\text { entre as práticas docentes que } \\
\text { utilizou e as práticas adotadas } \\
\text { por colegas que estão iniciando a } \\
\text { carreira como docentes formadores. }\end{array}$ \\
\hline $\begin{array}{l}\text { USA12; } \\
\text { USA14 }\end{array}$ & $\begin{array}{l}\text { 16. Percebe que suas aulas de lógica de } \\
\text { programação eram abordadas da mesma } \\
\text { maneira ainda que em cursos de níveis } \\
\text { diferentes. }\end{array}$ & $\begin{array}{l}15 \text { => (09): Entende que faltou } \\
\text { preparação formal para atuação } \\
\text { na docência na sua formação. }\end{array}$ \\
\hline
\end{tabular}

Fonte: As autoras.

\section{Quadro 3-Claude}

Participante da Pesquisa: o professor Claude é bacharel em Informática. Atua como professor desde 2013. Atualmente leciona as disciplinas de Redes de Computadores, Arquitetura de Computadores e Sistemas Operacionais na Licenciatura em Computação.

A descrição e o sentido do dito: Eu não tive nenhuma prática docente anterior à minha formação profissional (USS1). [...] A minha percepção em relação ao ensino não só no curso superior, mas também no curso médio, era de tentar vislumbrar dentro desse segmento a possibilidade de trazer a minha experiência técnica para a sala de aula (USS2). [...] A minha percepção no que diz respeito à licenciatura, ao ensinar, pelo menos, no início, era de viabilizar para esses alunos a minha experiência prática (USS3). Eu atuo nesse sentido de tentar possibilitar que esses alunos tenham dentro de sala de aula uma realidade parecida com a realidade que a gente vive dentro do mercado, dentro da área técnica (USS4). [...] Quando a gente forma um profissional licenciado em informática a gente tem algumas ramificações para esse profissional. [...] Ele pode migrar para uma área técnica (USS5). A grade de disciplinas técnicas que ele tem dentro do curso possibilita que ele vá atuar também no mercado (USS6). [...] Eu não vejo um profissional da Licenciatura de Informática específico só para a área de Licenciatura. Eu também vejo esse profissional com uma possibilidade de atuação dentro do mercado (USS7). [...] Na minha visão, o papel do professor é de atuar muito mais como um moderador do que uma pessoa que fica ali só passando informação (USS8). [...] $\mathrm{O}$ que me cabe, enquanto professor, é identificar pela experiência que eu tenho dentro desse ambiente corporativo que tipo de informação seria mais relevante para os alunos de forma que a gente pudesse trabalhar isso em sala de aula. [...] Mas também deixo aberto para que eles possam trazer informações para complementar esse processo (USS9). [...] Eu ensinei Informática Aplicada à Educação. Dentro dessa disciplina, eu faço um recorte diferenciado. [...] Busco fazer com que os alunos explorem quais são os ambientes tecnológicos que estão sendo trabalhados (USS10). [...] Com isso eu pretendo mostrar para eles a possibilidade de usar recursos tecnológicos para o ambiente de sala de aula. 


\begin{tabular}{|c|c|c|}
\hline \multicolumn{3}{|c|}{$\begin{array}{l}\text { Enxerto Hermenêutico: Mercado: refere-se ao espaço entre diferentes agentes (indivíduos, instituições, } \\
\text { órgãos de regulação, etc.) que se constitui pela incorporação de regras sociais que orientam as estratégias } \\
\text { e operações daqueles que utilizam o interior desse espaço (OLIVEIRA; PICCININI, 2011); Moderador: } \\
\text { papel representado pelo docente que exerce a mediação pedagógica com o intuito de intervir de modo } \\
\text { crítico e atuante na realidade do estudante, provocando a interação com outros indivíduos, a reflexão e } \\
\text { a transformação da/na vida cotidiana (CARDOSO; TOSCANO, 2011); Ambiente corporativo: organização } \\
\text { coletiva de pessoas com finalidades profissionais que buscam responder alguns desafios do momento, } \\
\text { levando em consideração os elementos de interdependência e integração dessas pessoas (BAVARESCO; } \\
\text { XIMENES; KONZEN, 2011); Recursos tecnológicos: ferramentas tecnológicas que auxiliam o processo de } \\
\text { ensino e aprendizagem (FIGUEIREDO; NOBRE; PASSOS, 2015). }\end{array}$} \\
\hline \multicolumn{3}{|c|}{ O sentido do dito articulado pelas pesquisadoras } \\
\hline $\begin{array}{c}\text { US da } \\
\text { Descrição }\end{array}$ & & \\
\hline USS1 & $\begin{array}{l}\text { 17. Lembra que não tev } \\
\text { prática docente antes }\end{array}$ & $\begin{array}{l}17=>(10): \\
\text { experiências } \\
\text { docente antes }\end{array}$ \\
\hline $\begin{array}{l}\text { USS2; USS3; } \\
\text { USS4 }\end{array}$ & $\begin{array}{l}\text { 8. Te } \\
\text { viv } \\
\text { pro }\end{array}$ & \multirow{2}{*}{$\begin{array}{l}18=>\text { (11): Compreende que sua } \\
\text { atuação consistia em trazer para a } \\
\text { sala de aula seus conhecimentos } \\
\text { prévios (suas experiências e } \\
\text { vivências anteriores) adquiridos } \\
\text { como profissional da área técnica. }\end{array}$} \\
\hline $\begin{array}{l}\text { USS5; USS6; } \\
\text { USS7 }\end{array}$ & $\begin{array}{l}\text { 19. Ent } \\
\text { atu } \\
\text { não }\end{array}$ & \\
\hline & $\begin{array}{l}\text { 20. Compreende que o professor deve atuar muito } \\
\text { mais no papel de moderador do que no de } \\
\text { transmissor de conteúdo. }\end{array}$ & $\begin{array}{l}19=>\text { (12): Entende que o } \\
\text { licenciado em computação pode } \\
\text { trabalhar em áreas diferentes da } \\
\text { educação. }\end{array}$ \\
\hline USS9 & $\begin{array}{l}\text { 21. Mantém } \\
\text { de forma } \\
\text { trabalho d }\end{array}$ & \multirow{2}{*}{$\begin{array}{l}\text { 20; } 21 ; 22 \text { => (13): Compreende } \\
\text { que o professor deve atuar como } \\
\text { um mediador do conhecimento, } \\
\text { estabelecendo relações dialógicas } \\
\text { com os estudantes, estimulando- } \\
\text { os a assumirem uma postura mais } \\
\text { autônoma enquanto realiza sua } \\
\text { prática docente. }\end{array}$} \\
\hline USS10 & $\begin{array}{l}\text { 22. Faz com que os estudantes assumam uma } \\
\text { postura mais independente ao possibilitar que } \\
\text { os mesmos explorem recursos tecnológicos que } \\
\text { possam ser usados na sala de aula. }\end{array}$ & \\
\hline
\end{tabular}

Fonte: As autoras. 


\section{Quadro 4-Carol}

Participante da Pesquisa: a professora Carol é graduada em Processamento de Dados. Trabalha com Educação a Distância, Modelagem e Mapas de Cognição. É professora desde 1995.

A descrição e o sentido do dito: Eu já iniciei na Licenciatura em Computação sempre no papel de professor formador (USC1). Era uma realização porque eu vinha de uma realidade diferente dos colegas. Eu não vim de empresas como a maioria deles. Eu já atuava na educação e a gente sentia a necessidade justamente da formação pedagógica desses colegas, e ter um curso que trouxesse esse viés de formação pedagógica, além da computação em si (USC2), era uma coisa muito boa. [...] A gente sempre buscou trabalhar de maneira interativa, fazendo com que os alunos construíssem o seu conhecimento, buscando fazer a interação e a interlocução da teoria com a prática (USC3). Outro ponto importante que a gente buscava trabalhar era a questão da transposição didática. [...] Às vezes é necessário algum artefato, algum objeto de aprendizagem que faça essa transposição se tornar mais fácil. [...] O trabalho com jogos é muito interessante porque traz o lúdico para o aluno (USC4). [...] Outra coisa que a gente trabalhava muito: a pedagogia de projetos (USC5). [...] Sempre nesse sentido de trazer o aluno na perspectiva do formador, do professor também. [...] A gente trazia uma vivência real e a partir dali ia buscando elementos para poder solucionar aquele problema (USC6). [...] A gente trabalhou muito também com a computação desplugada (USC7). [...] O diálogo com o outro é difícil. Por que é difícil até hoje se fazer projetos interdisciplinares? [...] Ninguém quer sair da sua zona de conforto para dialogar. [...] Você tem, hoje, diversas leis que têm a obrigatoriedade de se trabalhar com determinadas temáticas e há sempre a resistência da parte técnica. Talvez, justamente, pelo fato desse pessoal da área técnica não ter formação pedagógica (USC8). A partir do momento em que você tem uma formação pedagógica, você tem uma visão do todo, você vai perceber que assuntos transdisciplinares fazem parte do seu conteúdo, por mais técnico que seja tem como você envolver. [...] O envolvimento do aluno é muito maior; o aluno se sente como corresponsável por aquele processo de aprendizado (USC9). [...] Ele se sente um cidadão, muito nesse aspecto mesmo de poder entender a sociedade como um todo. [...] Você forma os alunos da Licenciatura para atuar na educação básica (USC10). [...] Qual é a sua função? É somente passar o conteúdo? Não. Você entra nesse papel como mediador (USC12). Você precisa identificar quais são os elementos que são fundantes para que você possa fazer o trabalho com a turma para que ela possa alcançar êxito. [...] Mesmo ensinando num curso de Licenciatura não é o mesmo perfil que ensinar para um bacharel, para um tecnólogo (USC13). Ele precisa trazer a prática como componente curricular para a disciplina dele (USC14). [...] Você está num curso de formação. Para a gente formar bons professores, a gente tem que pensar nessa perspectiva e não de professor detentor do conhecimento. [...] O papel do professor é de mediar e não mais de transmitir conhecimento (USC15).

Enxerto hermenêutico: Formação pedagógica: parte do DPD que está associada à construção do conhecimento pedagógico do/a docente. Este conhecimento pode ser compreendido como os meios utilizados pelos professores em relação aos/às estudantes, no processo de trabalho cotidiano, para obter um resultado (TARDIF, 2011); Transposição didática: adaptação do conhecimento científico de forma a adequá-lo às reais possibilidades cognitivas dos/as estudantes (CHEVALLARD, 2013); Objeto de aprendizagem: uma entidade, digital ou não digital, que pode ser usada, reusada ou referenciada durante o ensino com suporte tecnológico (TAROUCO et al., 2006); Pedagogia de projetos: refere-se ao desenvolvimento de uma cultura do aprender alicerçada a partir de quatro conceitos fundamentais (representação, identidade, negociação e redes) (VENTURA, 2002); Computação desplugada: alternativa para a execução de atividades que estimulam o pensamento computacional sem o uso de computadores, adequando-se melhor em espaços em que a infraestrutura tecnológica é deficiente ou ausente (FERREIRA et al., 2015); Prática como Componente Curricular (PCC): é uma trabalho consciente, de apoio ao processo formativo para dar conta dos múltiplos modos de ser da atividade acadêmicocientífica. O PCC deve envolver conhecimento e análise de situações pedagógicas diferenciando-se do estágio supervisionado, pois não depende da observação direta nas escolas (RIBEIRO, 2016).

\begin{tabular}{|c|c|c|}
\hline \multicolumn{4}{|c|}{ O sentido do dito articulado pelas pesquisadoras } \\
\hline $\begin{array}{c}\text { US da } \\
\text { Descrição }\end{array}$ & $\begin{array}{c}\text { Unidades de Significado articuladas } \\
\text { pelas pesquisadoras }\end{array}$ & $\begin{array}{c}\text { Ideias interpretadas pelas } \\
\text { pesquisadoras }\end{array}$ \\
\hline USC1 & $\begin{array}{l}\text { 23. Percebe que quando começou a ensinar na } \\
\text { Licenciatura em Computação já atuava como } \\
\text { professora formadora. }\end{array}$ & $\begin{array}{l}\text { 23; } 31 \text { => (14): Compreende } \\
\text { que realizava uma prática } \\
\text { intencionada à formação do } \\
\text { professor. }\end{array}$ \\
\hline USC2; USC8 & $\begin{array}{l}\text { 24. Sente que a falta da formação pedagógica em } \\
\text { alguns colegas professores de computação dificulta } \\
\text { o trabalho docente. }\end{array}$ & $\begin{array}{l}\text { 24 => (15): Entende que } \\
\text { formação pedagógica é } \\
\text { necessária ao trabalho docente. }\end{array}$ \\
\hline
\end{tabular}




\begin{tabular}{|c|c|c|}
\hline USC3 & $\begin{array}{l}\text { 25. Realiza o trabalho docente de forma interativa, } \\
\text { possibilitando a construção do conhecimento } \\
\text { por parte dos estudantes, fazendo a interação e a } \\
\text { interlocução da teoria com a prática. }\end{array}$ & \multirow{2}{*}{$\begin{array}{l}25 ; \mathbf{2 7} ; \mathbf{2 8} ; \mathbf{3 0}=>\text { (16): Realiza } \\
\text { a prática docente de maneira } \\
\text { sociointeracionista, valendo- } \\
\text { se de problemas reais e da } \\
\text { transdisciplinaridade para o } \\
\text { envolvimento dos estudantes } \\
\text { no processo de aprendizado. }\end{array}$} \\
\hline USC4 & $\begin{array}{l}\text { 26. Entende como importante para o trabalho docente } \\
\text { a utilização da transposição didática juntamente } \\
\text { com os objetos de aprendizagem e de jogos como } \\
\text { ferramentas de um ensino lúdico. }\end{array}$ & \\
\hline USC5 & $\begin{array}{l}\text { 27. Vale-se da pedagogia de projetos em sua prática } \\
\text { docente. }\end{array}$ & $\begin{array}{l}26 \text { => (17): Entende que aplica } \\
\text { a transposição didática em sua } \\
\text { prática docente. }\end{array}$ \\
\hline USC6 & $\begin{array}{l}\text { 28. Traz vivências reais para serem solucionadas na } \\
\text { prática docente. }\end{array}$ & \multirow{2}{*}{$\begin{array}{l}29 \text { => (18): Entende que aplica } \\
\text { a computação desplugada em } \\
\text { sua prática docente. }\end{array}$} \\
\hline USC7 & 29. Aplica a computação desplugada na prática docente. & \\
\hline USC9 & $\begin{array}{l}\text { 30. Percebe que assuntos transdisciplinares, quando } \\
\text { inseridos no conteúdo, levam os estudantes a } \\
\text { se sentirem corresponsáveis pelo processo de } \\
\text { aprendizado }\end{array}$ & $\begin{array}{l}32 \text { => (19): Compreende que } \\
\text { o docente deve atuar como } \\
\text { mediador. }\end{array}$ \\
\hline USC10 & $\begin{array}{l}\text { 31. Entende que os estudantes da Licenciatura são } \\
\text { formados para atuar na educação básica. }\end{array}$ & \multirow{2}{*}{$\begin{array}{l}33 \Rightarrow(20): \text { Entende que o } \\
\text { ensino deve ser diferenciado } \\
\text { em cursos com diferentes } \\
\text { titulações. }\end{array}$} \\
\hline $\begin{array}{l}\text { USC12; } \\
\text { USC15 }\end{array}$ & $\begin{array}{l}\text { 32. Compreende que o docente deve atuar no papel de } \\
\text { mediador. }\end{array}$ & \\
\hline USC13 & $\begin{array}{l}\text { 33. Entende que há diferenças entre ensinar em um } \\
\text { curso de Licenciatura e ensinar em um curso de } \\
\text { Bacharelado e/ou Tecnólogo. }\end{array}$ & \multirow{2}{*}{$\begin{array}{l}34=>\text { (21): Compreende que } \\
\text { a prática como componente } \\
\text { curricular deve estar inserida } \\
\text { nas disciplinas trabalhadas pelo } \\
\text { docente. }\end{array}$} \\
\hline USC14 & $\begin{array}{l}\text { 34. Compreende que a prática como um componente } \\
\text { curricular deve ser trabalhada pelo docente. }\end{array}$ & \\
\hline
\end{tabular}

Fonte: As autoras.

Diante das unidades de sentido destacadas e interpretadas nas descrições das transcrições das entrevistas, analisamos e articulamos $\mathbf{3 4}$ unidades de significado que foram sintetizadas em $\mathbf{2 1}$ ideias compreendidas nas descrições das entrevistas. Dessa forma, constituímos as unidades de significado e seguimos para o segundo movimento de redução: a análise nomotética.

\section{Segundo movimento de redução: análise nomotética (convergência das Unidades de Significado)}

Segundo Bicudo (2011, p. 58), "A análise nomotética indica o movimento de reduções que transcendem o aspecto individual da análise ideográfica". Nesse sentido, atentamo-nos à interrogação e, mediante outras duas reduções (dentro da análise nomotética), apontamos convergências que expressam o que está sendo dito do fenômeno - DPD de professores de computação não licenciados atuantes em uma Licenciatura em Computação -, isto é, as ideias nucleares que apontam para a estrutura do fenômeno pesquisado.

Para tanto, buscamos ouvir o que foi dito, focalizando, contudo, nas unidades de significado que foram expressas em 21 ideias interpretadas no primeiro movimento de redução. Agora, realizamos a primeira redução dentro da análise nomotética que consiste na reunião dos sentidos e significados que convergem de acordo com a nossa in- 
terpretação. Esse procedimento de escutar o dito mostrou-nos dez confluências sobre a prática docente, as quais apresentamos a seguir da seguinte forma: letra C representando o enunciado da confluência seguida do número da confluência.

As confluências foram surgindo a partir do momento em que nos perguntávamos o que dizem as primeiras ideias interpretadas das unidades de significado na análise ideográfica, que sentidos carregam consigo e que significados estão articulados nas palavras pronunciadas. O Quadro 6 apresenta as confluências. Esse Quadro está dividido em duas colunas. Na primeira reunimos aquelas ideias que pudessem convergir a uma particularidade da prática pedagógica, a qual encontra-se expressa na segunda coluna.

Quadro 6-Quadro de Convergências 1

\begin{tabular}{|c|l|}
\hline $\begin{array}{c}\text { Ideias interpretadas } \\
\text { pelos pesquisadores }\end{array}$ & \multicolumn{1}{|c|}{ Confluência } \\
\hline (1) e (2) & $\begin{array}{l}\text { C1: Prática docente afetada por colegas de trabalho e por experiência de } \\
\text { ensino vivenciada nas formaçães inicial e continuada. }\end{array}$ \\
\hline (3), (9), (10) e (15) & C2: Prática docente carecida da fundamentação de práticas pedagógicas. \\
\hline (4) e (16) & $\begin{array}{l}\text { C3: Prática docente permeada pela interação entre professor e estudante, } \\
\text { estudante e estudante e integrada por diferentes áreas do conhecimento. }\end{array}$ \\
\hline (5) & C4: Práticas docentes realizadas de maneira tradicional e conteudista. \\
\hline (6) e (12) & $\begin{array}{l}\text { C5: Prática docente direcionada à formação de profissionais para atuação em } \\
\text { áreas diferentes da educação. }\end{array}$ \\
\hline (7) e (8) & C6: Prática docente carecida dos saberes curriculares. \\
\hline (11) & $\begin{array}{l}\text { C7: Prática docente direcionada pela experiência de trabalhos anteriores e } \\
\text { marcada pela identidade profissional anterior ao trabalho docente. }\end{array}$ \\
\hline (14) & C8: Prática docente direcionada à atuação do professor na Educação Básica. \\
\hline (13) e (19) & C9: Prática docente voltada à mediação e autonomia dos estudantes. \\
\hline (17), (18), (20) e (21) & $\begin{array}{l}\text { C10: Prática docente realizada com aplicação de recursos da ciência pedagógica } \\
\text { e de acordo com as Diretrizes Curriculares Nacionais para a Formação Inicial } \\
\text { de Professores para a Educação Básica. }\end{array}$ \\
\hline
\end{tabular}

Fonte: As autoras.

A primeira confluência (C1) mostra-nos que a prática docente dos professores de computação não licenciados é afetada por colegas de trabalho e carrega em si experiências vivenciadas nas formações inicial e continuada. Essas experiências dizem respeito aos nossos conhecimentos acumulados que, agora, passam a funcionar como um código de referência (WAGNER, 1979). A partir do momento em que começamos a nos relacionar com outros colegas de trabalho, passamos a compreender a necessidade de buscar outros saberes da profissão docente que estão para além dos saberes específicos. Percebemos que diversas relações interpessoais afetam o trabalho docente e transformam a prática pedagógica.

A segunda confluência (C2) apresenta-nos que a prática docente dos professores de computação, no início da carreira como professor formador, é carecida de conhecimentos pedagógicos. Estes conhecimentos vão sendo construídos na medida em que vamos realizando o trabalho docente. Ressaltamos que a complementação pedagógica é imprescindível ao DPD de professores não licenciados, sendo ainda mais necessária 
quando esses professores assumem o papel de professor formador. Ter domínio do conteúdo a ser ensinado é tão importante quanto mostrar maneiras de como o conteúdo deve ser ensinado. Ensinar a ensinar é função do docente formador.

A terceira confluência (C3) exibe-nos que a interação entre professor e estudante e entre estudantes e estudantes direcionam o trabalho docente. Compreendemos que o professor de computação pode criar condições de aprendizagem de acordo com a capacidade cognitiva de cada estudante. Isso leva-nos a novas formas e métodos de ensino que podem ser aplicados nas práticas docentes, com a intenção de atender às reais necessidades de aprendizagem dos estudantes. É importante para o docente perceber o estudante como uma fonte de aprendizado, de aprimoramento de conhecimentos, de criação de novas práticas e metodologias de ensino. Dessa forma, ampliamos nossa consciência, refletimos cada vez mais sobre nossas ações, damos sentido e significado à nossa atuação enquanto formador, melhoramos nossa prática e, por consequência, aprimoramos nosso desenvolvimento profissional.

A quarta confluência (C4) mostra-nos que docentes de computação, no início da carreira como professor formador, ainda realizam uma prática de ensino tradicional e conteudista. Mesmo a literatura apresentando novas possibilidades de ensino, muitos professores valem-se do ensino tradicional. Percebemos que esse modo de orientação foi estimulado por práticas recebidas de outrem, antecessores a nós, que nos habituamos e que estão internalizadas como saberes adquiridos. Transformar nosso modo de agir, direcionando-nos a uma prática mais atual e inovadora, requer esforço, mudanças de crenças e paradigmas. Desafios que o docente de computação precisa enfrentar, bem como docentes de outras áreas.

A quinta confluência (C5) apresenta-nos que a prática docente de alguns professores de computação estava intencionada à formação do profissional da área de computação para atuação em campos diferentes da educação. A prática adotada por alguns não era condizente com o papel do professor formador. Esses sabiam o que ensinar, mas falhavam no como e no para quem se está ensinando. No início da carreira como professor formador, faltavam-Ihes conhecimentos acerca da profissionalidade docente.

A sexta confluência (C6) mostra-nos que a prática docente dos professores de computação carecia de saberes curriculares. Quando esses formadores começaram a ensinar na Licenciatura em Computação, muitos não tinham a percepção das diferentes concepções de currículo que compõem os diversos cursos da área de computação. Conscientemente, não distinguiam os currículos para os cursos da área de computação de diferentes titulações. Por isso, os conteúdos programáticos eram trabalhados da mesma forma tanto na Licenciatura quanto nos cursos de nível médio integrado e subsequente.

A sétima confluência (C7) expõe-nos que o professor de computação traz para a sua prática experiências profissionais vivenciadas fora da academia. Essas experiências representam seus conhecimentos adquiridos como profissional da área técnica. Antes de se tornar professor, o bacharel ou tecnólogo da área de computação, geralmente, já atuou profissionalmente como analista de sistemas, técnico de redes de computadores, 
programador, etc. Em virtude dessa atuação, eles carregam consigo uma bagagem de conhecimentos anteriores e uma identidade profissional que direcionam à sua prática logo que começam a lecionar.

A oitava confluência (C8) exibe-nos uma percepção de prática docente direcionada à atuação do licenciado em computação na educação básica. Percebemos que aqueles professores que tiveram experiências profissionais de ensino, antes de lecionar na Licenciatura em Computação, assumem conscientemente o papel de docente formador de futuros professores de computação. Isto porque eles já tinham incorporado alguns saberes e fazeres da profissão docente.

A nona confluência (C9) mostra-nos que há também professores de computação com uma visão mais renovada do processo de ensino e aprendizagem. Esses assumem uma postura em que o diálogo e a intermediação entre professores e estudantes prevalecem durante a prática docente, promovendo a construção do conhecimento por parte dos estudantes ao possibilitar um aprendizado mais autônomo e criativo.

A décima confluência (C10) apresenta-nos professores de computação que já iniciaram a carreia docente trazendo algum conhecimento pedagógico. Percebemos, nas narrativas desses docentes, que eles já tinham vivenciado experiências pedagógicas antes de começar a trabalhar como professor formador. Eles já traziam consigo conhecimentos sobre a profissionalidade docente; conhecimentos que estão postos em suas narrativas quando nos contam sobre suas ações práticas visando a atender às demandas internas e externas da instituição de ensino.

As confluências de um a dez representam articulações de ideias abrangentes, expressando generalidades do fenômeno pesquisado. Segundo Bicudo (2011), essas novas ideias devem ser articuladas em outras, ainda mais abrangentes e essenciais, a fim de constituir a estrutura do fenômeno interrogado. Realizamos, portanto, o terceiro movimento de redução, focalizando nas confluências que foram expostas no Quadro 6. Para diferenciar a nomenclatura, denominamos as convergências articuladas nesse segundo momento da redução nomotética de C2.1, C2.2, C2.3 e C2.4 e as apresentamos no Quadro 7.

Quadro 7-Quadro de Convergências 2

\begin{tabular}{|c|l|}
\hline $\begin{array}{c}\text { Ideias interpretadas } \\
\text { pelos pesquisadores }\end{array}$ & \multicolumn{1}{c|}{ Confluência } \\
\hline C1 e C7 & $\begin{array}{l}\text { C2.1: Prática docente afetada por experiências acadêmicas e profissionais } \\
\text { vivenciadas anteriormente ao trabalho como docente formador. }\end{array}$ \\
\hline C2, C4 e C6 & C2.2: Prática docente carecida de inovação e fundamentação pedagógica. \\
\hline C3, C9 e C10 & $\begin{array}{l}\text { C2.3: Prática docente mediada e realizada conforme as Diretrizes Curriculares } \\
\text { Nacionais para a Formação Inicial de Professores para a Educação Básica. }\end{array}$ \\
\hline C5 e C8 & $\begin{array}{l}\text { C2.4: Prática docente direcionada pelos diferentes campos de atuação para o } \\
\text { Licenciado em Computação. }\end{array}$ \\
\hline
\end{tabular}

Fonte: As autoras.

A Confluência 2.1 (C2.1) mostra-nos que o trabalho docente do professor de computação no início da carreira é bastante afetado pelas experiências vivenciadas anteriormente, sejam elas na academia ou em um ambiente profissional. O professor de 
computação traz para a sua prática as suas próprias experiências e também aquelas que foram transmitidas por colegas profissionais, por amigos e professores que, juntas, formam seus conhecimentos adquiridos ao longo da vida.

A Confluência 2.2 (C2.2) reúne os significados que representam o modo como esses docentes realizaram a prática pedagógica no início de sua atuação como docente formador. Percebemos que a maioria dos professores carecia do conhecimento pedagógico tão importante ao trabalho docente. Em razão disso, afirmamos que vários professores de computação não licenciados iniciaram o trabalho docente sem a capacitação formal para atuação em sala de aula. Essa falta de capacitação deve ser preenchida com a devida formação, de modo que suas ações fiquem mais condizentes com as novas metodologias de ensino exigidas pelo mundo contemporâneo e também por nós profissionais do ensino e da educação.

Se faltou formação pedagógica para alguns participantes, outros, contudo, iniciaram a carreira com esse conhecimento. Dessa forma, reunimos, na Confluência 2.3 (C2.3), os significados que mostram a prática docente dos professores de computação sendo conduzida pela ciência pedagógica e pelas diretrizes curriculares nacionais. Nesse tipo de prática observamos novas metodologias de ensino sendo trabalhadas, assim como assuntos transdisciplinares sendo introduzidos no conteúdo programático do componente curricular ofertado.

A Confluência 2.4 (C2.4) mostra-nos que a percepção dos professores de computação sobre os possíveis campos de atuação dos egressos do curso de Licenciatura em computação direciona a prática docente desses formadores. Ainda que percebamos nas narrativas dos participantes visões diferentes sobre a atuação profissional desses licenciados, todas elas (as visões) estão contempladas nos planos de curso da Licenciatura em Computação do Ifba. Assim, o licenciado em computação poderá atuar em diversas áreas educacionais e não apenas como docente de disciplinas da área de Computação na Educação Básica.

Seguindo no movimento de redução, afluímos as convergências C2.1, C2.2, C2.3 e C2.4 em apenas um núcleo de significados que nomeamos e explicitamos como práticas docentes (in)determinadas. Ele representa o núcleo de ideias que constitui a estrutura do fenômeno pesquisado e indica o modo pelo qual professores não licenciados, da área de computação, vivenciaram o trabalho docente quando começaram a lecionar na Licenciatura em Computação.

Esse núcleo apresenta-nos que o ensino da computação carrega em si múltiplas (in)determinações, as quais afetam o trabalho dos professores de computação. No modo como esses docentes realizam suas práticas, eles impingem, principalmente, suas experiências obtidas como profissionais de áreas técnicas e/ou experiências adquiridas nas formações iniciais e continuadas. Além disso, o núcleo mostra-nos que os professores de computação compreendem o trabalho docente na dimensão do contexto de vida experienciada por eles, não se orientando, inicialmente, em concepções teóricas e pedagógicas. Assim, percebemos que o núcleo - práticas docentes (in)determinadas - manifesta a essência do desenvolvimento profissional desses professores segundo o modo pelo qual esses profissionais o compreendem. Na próxima seção apresentamos nossa interpretação referente ao núcleo supracitado. 


\section{O que expressa o núcleo de significado práticas docentes (in)determinadas?}

O movimento de interpretação é importante porque mostra a compreensão das pesquisadoras sobre o fenômeno que está sendo investigado. Seja nos momentos de trabalho, lazer ou de produção científica, estamos sempre interpretando e buscando explicitar o que percebemos e refletimos, e nos pronunciamos por meio de linguagem, comunicando o percebido, o sentido (VENTURIN, 2015).

A interpretação consiste em um empenho de comunicar o dito (pelos participantes, teóricos e estudiosos da área) em uma costura entrelaçada e contemplativa de enxergar e exprimir além do que está posto. Temos uma proposição estrutural que nos mostra que os docentes participantes, de modo geral, não pautaram a prática docente nem o ensino da computação em concepções teóricas, mas em um fazer empírico que vai sendo apreendido na medida em que se faz.

Conforme exposto, o núcleo de significado, com práticas docentes (in)determinadas, foi constituído com os sentidos e os significados que se manifestaram com as confluências C2.1 (prática docente afetada por experiências anteriores ao trabalho docente), C2.2 (prática docente carecida de inovação e fundamentação pedagógica), C2.3 (prática docente mediada e realizada conforme legislação vigente) e C2.4 (prática docente direcionada pelos diferentes campos de atuação do licenciado em computação). Esse movimento que ora alcançamos mostra nossa compreensão e interpretação sobre uma parte e um período específico do DPD do professor de computação, a saber: experiências de práticas docentes do professor de computação não licenciado nos anos iniciais de atuação no curso de Licenciatura em Computação.

Ao analisar as entrevistas, compreendemos, segundo as narrativas dos participantes, que o professor de computação vivencia a prática docente conforme sua consciência e motivações. Muitos desses profissionais no início da carreira ainda desconhecem os saberes e fazeres da profissão docente, e, diante disso, não os vinculam à sua prática. O saber do professor está relacionado, entre outras coisas, com a sua pessoa, sua identidade, suas próprias experiências e com aquelas que lhes são transmitidas por seus professores além de sua história profissional, que, na forma de conhecimento à mão, funcionam como referência (TARDIF, 2011; WAGNER, 1979).

Dessa forma, percebemos na entrevista do professor Claude que o saber-fazer da sua prática, em alguns momentos, não estava associado ao saber-fazer docente, mas, sim, à sua atuação como profissional técnico inserido em um ambiente corporativo. Em sua narrativa, Claude afirma que atuava no sentido de tentar possibilitar aos estudantes uma realidade parecida com a realidade que ele vivenciou dentro do mercado de trabalho.

A professora Ada, por sua vez, já tinha experiência docente antes de ensinar na Licenciatura em Computação, mas atuava como uma professora tecnicista e conteudista. Ela assevera que se utilizava da metodologia de ensino tradicional, que consistia em trazer o conteúdo teórico, explicar aqueles conteúdos e tentar aplicá-los na prática usando as ferramentas que estivessem disponíveis naquele momento. 
Ada salienta que não recebeu amparo para atuar em sala de aula. Ante a necessidades formativas, ela adotava as mesmas práticas tanto na Licenciatura quanto no Bacharelado e nos cursos técnicos. Quando a professora Ada começou a lecionar na Licenciatura em Computação, ela ainda não tinha a percepção de que os currículos não são os mesmos para cursos de diferentes titulações, mesmo sendo em áreas iguais. Em sua entrevista, ela declara que trabalhava com a Licenciatura da mesma maneira que trabalhava com o Bacharelado.

Diante do exposto, nossa compreensão e interpretação sobre a prática do docente formador de professor de computação mostra uma discrepância existente entre o saber-fazer do professor, ensinado pelos estudiosos da área, e a prática real adotada na sala de aula. Essa desconexão ocorre, comumente, porque os docentes formadores de professores de computação pareciam desconhecer os elementos constitutivos do trabaIho docente, as discussões sobre propostas pedagógicas, currículos, avaliações e outros elementos que fazem parte do processo de ensino e aprendizagem.

$\mathrm{Na}$ falta desses conhecimentos, o professor que inicia sua carreira sem passar por processos formais de preparação para a docência, pode tornar-se um mero executor de ementas de disciplinas anteriormente elaboradas à sua chegada na instituição de ensino (DE OLIVEIRA; DA CRUZ, 2017). O desconhecimento do ofício que executamos nos limita e interfere nas nossas ações, gerando conflitos e incertezas em nossas atuações. Por isso, compete ao professor bacharel ou tecnólogo buscar, de forma obrigatória, os saberes inerentes à profissão docente (saberes próprios do nosso ofício). Quando nos apropriamos do saber-fazer docente refletimos muito mais sobre nossas ações, o que possibilita uma maior clareza sobre as condições que nos levam a agir de uma ou outra forma.

Pela análise das entrevistas, compreendemos que quando os professores de computação já se percebem como professores formadores, a prática docente é direcionada à construção do conhecimento pelos estudantes. O professor não mais se coloca na posição de transmissor do conhecimento; ele, juntamente com os estudantes, é corresponsável pelo processo de aprendizado. Essa mudança de paradigma foi percebida nas entrevistas da professora Carol e do professor Marvin.

No início de sua atuação, Marvin deixa claro que agia conforme suas motivações. O modo como realizava sua prática pode ser interpretado analisando as categorias de motivos estabelecidas por Schutz (2018). Assim, quando Marvin afirma que o direcionamento que ele deu para suas primeiras aulas, na Licenciatura, foi baseado nas experiências da Graduação, ele expressa a categoria de motivos (Weil-Motiv) que remete a experiências passadas, as quais determinaram o modo de suas ações. Ele volta-se à experiência vivida, abrangendo fatores psicológicos e sociais de sua pessoa (Ibid).

O professor Marvin foi bastante afetado (influenciado) pelo grupo de pesquisa do qual fazia parte. Ao narrar que o grupo oportunizou-lhe refletir mais sobre extensão, pesquisa e práticas de ensino, ele compreende seu desenvolvimento profissional como uma rede de relações sociais em que reflexões e ressignificações das experiências, vivenciadas no ambiente acadêmico, são essenciais ao crescimento e à transformação do seu ser enquanto docente e, consequentemente, à melhoria de sua prática profissional. 
Mesmo tendo em seu acervo um conhecimento pedagógico adquirido em sua formação continuada, Marvin entende como necessária a complementação pedagógica para os docentes não licenciados que atuam como professores formadores. Essa mesma percepção tem a professora Carol. Por atuar na educação há um bom tempo e já conhecer diversos saberes e fazeres da profissão docente, ela expressa a necessidade da formação pedagógica para bacharéis e tecnólogos que estão atuando como formadores de futuros professores.

Compreendemos, também, que os professores de computação têm interpretações diferenciadas sobre o perfil dos egressos do curso de Licenciatura em Computação. O professor Claude entende que o licenciado em computação pode migrar para uma área técnica. Para Claude, a Licenciatura em Computação (em virtude da grade de disciplinas técnicas) possibilita ao licenciado atuar também no mercado de trabalho. Ele narra que não vê o licenciado em computação como uma pessoa específica só para atuar na docência. Ele enxerga uma possibilidade de atuação para esse profissional fora do mundo da vida escolar.

Por outro lado, a professora Carol entende a Licenciatura em Computação como um curso de formação em que se forma pessoas para atuar na educação básica. Percebemos que essas diferentes interpretações dadas ao perfil do egresso, refletem no modo de agir (na prática) de cada professor. Essas diferentes interpretações sobre o perfil do egresso nos mostra intenções formativas distintas, porém leva-nos a um ponto de convergência que é a formação de pessoas para assumir uma profissão, ou seja, a formação de profissionais que atuarão em uma instituição de ensino ou fora dela. Desse modo, compreender o DPD, a partir da teoria pensada por Alfred Schutz, significa percebê-lo como um projeto humano que abrange motivações, ações, escolhas, análises e reflexões.

Na próxima seção apresentamos uma breve síntese sobre o que compreendemos em torno da interrogação: Como professores de computação não licenciados percebem seu desenvolvimento profissional nos anos iniciais do exercício docente na Licenciatura em Computação?

\section{SÍNTESE COMPREENSIVA E IMPLICAÇÕES DO FENÔMENO INVESTIGADO}

O tema desta pesquisa focou uma parte do desenvolvimento profissional docente de professores bacharéis ou tecnólogos da área de computação. Nesse sentido, a interrogação caminhou em direção ao questionamento da percepção que esses professores têm (ou tiveram) sobre seu desenvolvimento profissional nos anos iniciais do exercício docente na Licenciatura, ou seja, como esses profissionais experienciaram a prática docente nos três primeiros anos de atuação como professores formadores atuantes em uma Licenciatura em Computação.

Por se tratar de um estudo que tem como fundamentação teórica a sociologia fenomenológica de Alfred Schutz, atentamos para a adequação do sentido, ou seja, não fizemos interpretações que não se referissem à própria experiência da pessoa. Dado que em Schutz os sentidos e os significados de nossas ações estão entrelaçados no tempo, colocamo-nos em um movimento de buscar compreender as ações docentes em 
um determinado período de tempo, que, no caso desta pesquisa, diz respeito ao período inicial de atuação do docente de computação, especificamente na Licenciatura em Computação.

Durante todo caminhar da investigação, atentamos para a suspensão de nossos pressupostos que levam em conta o nosso conhecimento adquirido, deixando-nos guiar pelo conjunto metodológico adotado, ou seja, cuidamos para colocar em epoché nossos conceitos anteriores de forma que eles não dirigissem nosso olhar, quer no momento em que entrevistamos os participantes quer no momento de análise do exposto pelos entrevistados. Entendemos o desenvolvimento profissional docente de professores formadores da área de computação como um espaço novo e aberto para pesquisas que busquem investigar o ensino, os currículos e a formação docente dos professores que ensinam computação.

O curso de Licenciatura em Computação é relativamente novo quando comparado a outros cursos de formação de professores, carecendo, portanto, de mais pesquisas e também de formações continuadas dentro do próprio ambiente de trabalho, por exemplo, as atividades complementares que se configuram como uma instância de formação continuada permanente desenvolvida na própria instituição de ensino e respaldadas por legislação própria.

Ademais, interpretamos que a prática docente (nos anos iniciais de atuação na Licenciatura) dos professores entrevistados não estava orientada por concepções teóricas e/ou pedagógicas. Ela vinha assinalada de experiências laborais, vivenciadas nos espaços onde esses formadores atuaram profissionalmente, e/ou vinha marcada pelas relações sociais que foram sendo constituídas ou destituídas durante suas trajetórias formativas.

\section{REFERÊNCIAS}

BACICH, Lilian. Ensino Híbrido: Proposta de formação de professores para uso integrado das tecnologias digitais nas ações de ensino e aprendizagem. In: WORKSHOP DE INFORMÁTICA NA ESCOLA (WIE), 22., CONGRESSO BRASILEIRO DE INFORMÁTICA NA EDUCAÇÃO, 5., 2016. Uberlândia. Anais [...]. Uberlândia: CBIE, 2016. p. 679-687.

BAVARESCO, Agemir; XIMENES, João de Araújo; KONZEN, Paulo Roberto. Corporação: instituição hegeliana. Filosofazer, v. 1, n. 39, p. 29-61, jul./dez. 2011.

BICUDO, Maria Aparecida Viggiani. Análise fenomenológica estrutural e variações interpretativas. In: BICUDO, Maria Aparecida Viggiani (org.). Pesquisa qualitativa segundo a visão fenomenológica. 1. ed. São Paulo: Cortez, 2011, p. 53-74. V. 1.

CAMBRAIA, Adão Caron; PEDROSO, Eliana Fritzen. Construção identitária do professor de computação na integração curricular. Revista Contexto \& Educação, ljuí, v. 32, n. 103, p. 5-28, set./dez. 2017.

CAMBRAIA, Adão Caron; ZANON, Lenir Basso. Desenvolvimento profissional docente na recriação da prática curricular em computação - por uma reforma do pensamento/ação. Tecné Episteme y Didaxis: TED, número extraordinário, v. 2, p. 1-6, out./nov. 2018.

CARDOSO, Leila Aparecida Assolari; TOSCANO, Carlos. A mediação pedagógica na sala de aula: o papel do professor na construção do conhecimento. In: SEMINÁRIO INTERNACIONAL DE REPRESENTAÇÕES SOCIAIS, EDUCAÇÃO E SUBJETIVIDADE (SIRSSE). 1., CONGRESSO NACIONAL DE EDUCAÇÃO (EDUCERE), 10., 2011. Curitiba. Anais [...]. Curitiba: Educere, 2011. p. 13.466-13.475.

CHEVALLARD, Yves. Sobre a teoria da transposição didática: algumas considerações introdutórias. Revista de Educação, Ciências e Matemática, v. 3, n. 2, p. 1-14, maio/ago. 2013.

DA SILVA, Andréa Villela Mafra. A pedagogia tecnicista e a organização do sistema de ensino brasileiro. Revista HISTEDBR On-line, v. 16, n. 70, p. 197-209, dez. 2016. 
DE OLIVEIRA, Tatiana Pinheiro; DA CRUZ, Giseli Barreto. Inserção profissional docente no Ensino Superior. Education Policy Analysis Archives/Archivos Analíticos de Políticas Educativas, n. 25, p. 1-23, 2017.

FERREIRA, Ana Carolina; MELHOR, André; BARRETO, Jandiaci; PAIVA, Luiz Fernando de; MATOS, Ecivaldo. Experiência prática interdisciplinar do raciocínio computacional em atividades de computação desplugada na educação básica. In: WORKSHOP DE INFORMÁTICA NA ESCOLA (WIE), 4., CONFERÊNCIA LATINO-AMERICANA DE OBJETOS E TECNOLOGIAS DE APRENDIZAGEM, 10., 2015. Maceió. Anais [...]. Maceió, 2015, p. 256-265.

FERREIRA, Vinícius; CANEDO, Edna. A autenticidade na aprendizagem baseada em projetos para desenvolvimento de software: uma revisão sistemática de literatura. In: SIMPÓSIO BRASILEIRO DE INFORMÁTICA NA EDUCAÇÃO (SBIE), 30., 2019. Brasília. Anais [...]. Brasília: Congresso Brasileiro de Informática na Educação (CBIE), 2019. p. 41-50.

FIGUEIREDO, Gislaine; NOBRE, Isaura; PASSOS, Marize Lyra Silva. Tecnologias computacionais na educação: Desafios na prática docente. In: WORKSHOP DE INFORMÁTICA NA ESCOLA (WIE), 4., CONFERÊNCIA LATINO-AMERICANA DE OBJETOS E TECNOLOGIAS DE APRENDIZAGEM, 10., 2015. Maceió. Anais [...]. Maceió, 2015, p. 127-136.

FRANCO, Maria Amélia do Rosário Santoro. Prática pedagógica e docência: um olhar a partir da epistemologia do conceito. Revista Brasileira de Estudos Pedagógicos, v. 97, n. 247, p. 534-551, 2016.

GORZONI, Sílvia de Paula; DAVIS, Claudia Leme Ferreira. O conceito de profissionalidade docente nos estudos mais recentes. Cadernos de Pesquisa, v. 47, n. 166, p. 1.396-1.413, 2017.

HUBERMAN, Michael. O ciclo de vida profissional dos professores. In: NÓVOA, António (org). Vidas de professores. 2. ed. Porto: Porto, 2000.

LICHTMAN, Marilyn. Qualitative research in education: A User's Guide. 2. ed. Thousand Oaks, CA: Sage, 2012.

MACHADO, Lucília. O profissional tecnólogo e sua formação. Revista da RET - Rede de Estudos do TrabaIho, v. 1, n. 3, p. 20-49, 2008.

MARCELO, Carlos. Desenvolvimento profissional docente: passado e futuro. Sísifo-Revista de Ciências da Educação, v. 8, p. 7-22, jan./abr. 2009.

OLIVEIRA, Sidinei Rocha de; PICCININI, Valmiria Carolina. Mercado de trabalho: múltiplos (des) entendimentos. Revista de Administração Pública, v. 45, n. 5, p. 1.517-1.538, 2011.

PAIVA, Luiz Fernando de; BOMPET, Pietro; CORLETT; Emilayne Feitosa; MATOS, Ecivaldo; SCHWARZELMULLER, Anna. A formação, o trabalho e a identidade profissional do professor de Computação: um mapeamento sobre a Licenciatura em Computação. In: WORKSHOP DO CONGRESSO BRASILEIRO DE INFORMÁTICA NA EDUCAÇÃO (WEI), 25., 2017. São Paulo. Anais [...]. São Paulo: Congresso da Sociedade Brasileira de Computação (CSBC), 2017. p. 893-901.

RIBEIRO, Márcia Maria Gurgel. Prática como componente curricular. Centro de Educação Universidade Federal do Rio Grande do Norte. FORUMDIR. 2016. Disponível em: http://portal.mec.gov.br/docman/abril-2016/37541-cne-seminario-formacao-professores-2016-apresentacao-06-marcia-gurgel-pdf/file, 2016.

SCHUTZ, Alfred. A construção significativa do mundo social: uma introdução à sociologia compreensiva. Tradução Tomas da Costa. Petrópolis, RJ: Vozes, 2018.

SILVA, Fernanda Quaresma da. Docência universitária: de bacharel a professor nos cursos de Ciência da Computação e Sistemas de Informação. 2018. 153 f. Dissertação (Mestrado em Educação) - Universidade Federal de Uberlândia, Programa de Pós-Graduação em Educação, Uberlândia, 2018.

SILVA, Maria de Lourdes. A intencionalidade da consciência em Husserl. Argumentos: Revista de Filosofia, v. 1, n. 1, p. 45-53, 2009.

SILVA, Ranansamir Sousa da; MATOS, Ecivaldo de Souza; MASSA, Monica de Sousa. O desenvolvimento da identidade docente por professores de Computação não licenciados atuantes na Educação Profissional de Nível Médio. In: WORKSHOP SOBRE EDUCAÇÃO EM COMPUTAÇÃO (WEI), 26., 2018, Natal. Anais [...]. Natal: Congresso da Sociedade Brasileira de Computação (CSBC), 2018.

TARDIF, Maurice. $O$ trabalho docente, a pedagogia e o ensino. Interações humanas, tecnologias e dilemas. In: TARDIF, Maurice. Saberes docentes e formação profissional. 12. ed. Petrópolis, RJ: Vozes, 2011.

TAROUCO, Liane; KONRATH, Mary Lúcia; CARVALHO, Marie Jane; AVILA, Bárbara. Formação de professores para produção e uso de objetos de aprendizagem. Renote-Revista Novas Tecnologias na Educação, v. 4, n. 1, p. 1-10, jun./jul. 2006. 


\section{\& Contexto}

Desenvolvimento Profissional de Professores de Computação: uma Análise das Práticas Docentes

VALENTE, José Armando. A sala de aula invertida e a possibilidade do ensino personalizado: uma experiência com a Graduação em midialogia. In: BACICH, Lilian; MORAN, José (org.). Metodologias ativas para uma educação inovadora: uma abordagem teórico-prática. 1. ed. Porto Alegre: Penso, 2018. p. 2644. V. 1.

VENTURA, Paulo Cezar Santos. Por uma pedagogia de projetos: uma síntese introdutória. Educação \& Tecnologia, v. 7, n. 1, p. 36-41, jan./jun. 2002.

VENTURIN, Jamur Andre. A educação matemática no Brasil da perspectiva do discurso de pesquisadores. 2015. 541 f. Tese (Doutorado em Educação Matemática) - Universidade Estadual Paulista "Júlio de Mesquita Filho", Instituto de Geociências e Ciências Exatas, Rio Claro, 2015.

WAGNER, Helmut R. (org.). Fenomenologia e relações sociais: textos escolhidos de Alfred Schutz. Tradução Ângela Melin. Rio de Janeiro: Zahar, 1979. 